\title{
First record of Muellerius capillaris (Nematoda, Protostrongylidae) in northwestern Argentina
}

\author{
V. H. SUAREZ ${ }^{1 *}$, E. A. BERTONI ${ }^{1}$, J. F. MICHELOUD ${ }^{1}$, M. M. CAFRUNE ${ }^{1}$, A. E. VIÑABAL ${ }^{1}$, \\ J. QUIROGA ROGER ${ }^{2}$, A. F. BASSANETTI ${ }^{1}$
}

\author{
${ }^{1}$ INTA - Estación Experimental Agropecuaria Salta, RN 68, km 172, 4403 Cerrillos, Salta, Argentina, \\ *E-mail: suarez.victor@inta.gob.ar; ${ }^{2} \mathrm{INTA}$ - IPAF NOA, RN 9 km 1763, 4622 Posta de Hornillos, Jujuy, Argentina
}

\begin{abstract}
Summary
Seven flocks of different composition of goat and/or sheep were evaluated for the presence of Muellerius capillaris (Mueller 1889) in sites of different climatic conditions and under different management practices in northwestern Argentina. The nematode was recovered and identified in four goat flocks and two mixed goat and sheep flocks. Three goat flocks and both mixed goat and sheep flocks were located in Lerma Valley (Salta), with the other goat flock located in Quebrada de Humahuaca (Jujuy). M. capillaris was not detected in the Puna of Jujuy (3500 m a.s.l.). First-stage larvae were recovered from fecal samples using the Baermann technique. Lungs from six goats revealed numerous small pulmonary nodules and areas of emphysema, as well as a small number of $M$. capillaris adults. This is the first report of M. capillaris in Argentina.
\end{abstract}

Keywords: Muellerius capillaris; goats; sheep; northwestern Argentina

\section{Introduction}

Livestock production in valleys and gorges in northwestern Argentina relies heavily on small ruminants, mostly goats, which are the main income for small-scale producers of milk and meat, along with family agriculture. Therefore, diagnosing and preventing sanitary problems of small ruminants is critical for determining competitiveness in these systems.

The protostrongylid nematode Muellerius capillaris (Mueller 1889) is a roundworm that parasitizes the lungs of goats and sheep, and other wild ruminants in several regions worldwide. In some areas, such as the Mediterranean basin, its prevalence reaches almost $100 \%$ of adult individuals, especially goats, which exhibit a higher prevalence than sheep. In Eurasia and North Africa, mixed infections with other lung nematodes are frequent (Cabaret, 1984).

This lungworm is found in the bronchioles and small air- ways, as well as the pulmonary alveoli and subpleural tissue. Although the pathogenic effects of $M$. capillaris are low compared to those of other nematodes (Suárez, 2007), cases of respiratory difficulties, chronic bronchopneumonia (Berrag \& Cabaret, 1996), and interstitial pneumonia have been mentioned. This species has also been reported as a predisposing agent for bacterial infections and production losses (Pandey et al., 1984; Thomson et al., 2000). Adults of M. capillaris are ovoviviparous, laying eggs that hatch into first-stage larvae (L1) after migrating from the nodules to the airways. From the airways, they pass through the digestive tract and are shed in the feces. Due to their indirect life cycle, once in the external environment, L1 must find an intermediary host, such as numerous mollusk species of the genera Helix and Deroceras (Cabaret, 1981). Mollusks in contact with $\mathrm{L} 1$ become infected and develop into L2 (8 days) and then into L3 (15 days). Small ruminants become infected by ingesting the small mollusks contaminated with L3 or directly by feeding on infested grasses. After migrating to the lungs, the lungworms penetrate the alveolar spaces and induce the formation of a granulomatous nodule. During the prepatent period ( $3-5$ weeks to some months) L3 develop into L4 and then into adult forms capable of reproducing and lay eggs (Cabaret, 1984).

In the Americas, M. capillaris has been reported in the United States, Canada, Brazil and Chile (Nimmo, 1979; Pybus \& Shave, 1984; Machado \& Lima, 1988; Alcaino \& Gorma, 1999), with no records in Argentina to date. Here, we provide the first record of $M$. capillaris in goats and sheep in northwestern Argentina.

\section{Materials and methods}

The samples analyzed were collected from animals raised in Lerma Valley (Salta province) and in Quebrada de Humahuaca and the Puna (Jujuy province). The climate in Lerma Valley is temperate, typical of highland valleys 
Table 1. Sampling data, type of analysis and prevalence of recovered Muellerius capillaris L1 for each flock and location

\begin{tabular}{|c|c|c|c|c|c|c|}
\hline $\begin{array}{l}\text { Flock and } \\
\text { Location }\end{array}$ & $\begin{array}{c}\text { Sampling } \\
\text { date }\end{array}$ & $\begin{array}{l}\text { Analysis } \\
\text { Type }\end{array}$ & $\begin{array}{c}\mathrm{N}^{\circ} \text { of } \\
\text { samples }\end{array}$ & $\begin{array}{l}N^{\circ} \text { of } \\
\text { pools }\end{array}$ & $\begin{array}{c}\mathrm{N}^{\circ} \text { of positive } \\
\text { samples }\end{array}$ & $\begin{array}{c}\text { Mean } \\
\text { prevalence } \\
(\%) \\
\end{array}$ \\
\hline $\begin{array}{c}\text { A } \\
\text { Lerma Valley }\end{array}$ & $\begin{array}{c}\text { Dec } 12 \\
\text { Jul } 13 \\
\text { Aug } 14\end{array}$ & individual & 69 goat & - & 60 & 86.9 \\
\hline $\begin{array}{c}\text { B } \\
\text { Lerma Valley }\end{array}$ & $\begin{array}{l}\text { Aug } 13 \\
\text { Dec } 13\end{array}$ & individual & $\begin{array}{l}18 \text { goat } \\
15 \text { sheep }\end{array}$ & - & $\begin{array}{c}13 \\
5\end{array}$ & 54.5 \\
\hline $\begin{array}{c}\text { C } \\
\text { Lerma Valley }\end{array}$ & $\begin{array}{l}\text { Sept } 13 \\
\text { Sept } 14\end{array}$ & pool & $\begin{array}{l}17 \text { goat } \\
11 \text { sheep }\end{array}$ & $\begin{array}{l}3 \\
5\end{array}$ & $\begin{array}{l}0 \\
4\end{array}$ & - \\
\hline $\begin{array}{c}\text { D } \\
\text { Lerma Valley }\end{array}$ & $\begin{array}{c}\text { Mar } 13 \\
\text { Apr } 13 \\
\text { May } 13 \\
\text { Jul } 13\end{array}$ & individual & 174 goat & 15 & 3 & - \\
\hline $\begin{array}{c}\text { E } \\
\text { Lerma Valley }\end{array}$ & Apr 13 & pool & 12 goat & 1 & 1 & - \\
\hline $\begin{array}{c}\text { F } \\
\text { Quebrada de } \\
\text { Humahuaca }\end{array}$ & $\begin{array}{c}\text { Jul } 13 \\
\text { Aug } 13 \\
\text { Dec } 13\end{array}$ & Individual & 69 goat & 19 & 8 & - \\
\hline $\begin{array}{c}\text { G } \\
\text { The Puna }\end{array}$ & $\begin{array}{l}\text { Nov10 } \\
\text { Feb } 11 \\
\text { Apr } 11\end{array}$ & pool & 96 sheep & 10 & 0 & - \\
\hline
\end{tabular}

(1050 m a.s.1.) in northwestern Argentina. Precipitation is concentrated in the summer, with a dry period from April to November; mean annual precipitation ranges from $700-$ $800 \mathrm{~mm}$ in the central and southern portions of the valley to $1000 \mathrm{~mm}$ in the northwestern parts. Mean annual temperature is $17^{\circ} \mathrm{C}$ (maximum: $36^{\circ} \mathrm{C}$; minimum: $-6{ }^{\circ} \mathrm{C}$ ), with a relative environmental humidity between 20 and $80 \%$. Quebrada de Humahuaca is located at $2200 \mathrm{~m}$ a.s.1., whereas the Puna ecoregion at above $3500 \mathrm{~m}$ a.s.1. The study area in both regions has a seasonal precipitation regime ranging between 180 and $250 \mathrm{~mm}$, distributed from December to March (austral summer) with a mean temperature of 7.1 to $14{ }^{\circ} \mathrm{C}$ and great daily thermal amplitude.

Samples were taken from seven flocks (labeled A, B, C, D, $\mathrm{E}, \mathrm{F}$ and $\mathrm{G})$. Flocks $\mathrm{A}, \mathrm{B}, \mathrm{C}, \mathrm{D}$, and $\mathrm{E}$ were located in Lerma Valley (Salta), while flocks $F$ and $G$ were located respectively in Quebrada de Humahuaca and the Puna (Jujuy). Flocks A, B and C were subjected to extensive management, with flock A including only goats and flocks $\mathrm{B}$ and $\mathrm{C}$ including goats and sheep. All three flocks were located in the northern portion of Lerma Valley, with flock A being located in the environment with the highest precipitation in the valley. Flocks D, E and F were composed only of goats and subjected to a more intensive management, with irrigated pastures and annual crops, and stabling periods. Finally, flock G, which included only sheep and was subjected to extensive management on pastures. The genetic origin of the sampled goats was Criollo in B, $\mathrm{C}$ and $\mathrm{F}$, and crosses of Criollo with dominance of Saanen in A, D and E. Sheep of flocks B and C were Criollo breed and $\mathrm{G}$ sheep were Corriedale and Merino breeds.

Fecal samples were obtained from adult individuals of all the seven flocks; number of individuals, pool numbers (mixture), and sampling dates for each flock are detailed in Table 1. In addition, samples were collected from young goats (ranging between six and eleven months old) of flocks $\mathrm{D}$ and $\mathrm{F}$ in November $(\mathrm{n}=15)$ and December $(\mathrm{n}=20)$ 2013 in order to perform two pools.

The lungs of individuals sacrificed for consumption were examined: four goat lungs in flock A (two in December 2012, one in January 2013 and one in January 2014); two goat lungs in flock B, (one in August 2013 and the other in January 2014); four sheep lungs in flock G (two in February 2011 and two in October 2011). The presence of L1 was observed using Baermann technique (Suarez, 1997), which has been shown to be efficient in recovering lungworms (Papadopoulos et al., 2004). This technique was performed both in individual samples and in pools of several individual samples. L1s were identified using the morphological characters described by Van Wyk et al. (2004). Adult forms were recovered in two steps. First, the lungs were palpated in order to detect the presence of nodules; then they were dissected off to find adult worms. Parasites were extracted from the tissue by gentle compression between two glass sides, and then carefully teased the parasites away from the tissues with thumb forceps. Then, to collect the remaining adult worms, the nodules were cut into several pieces, submerged in warm water $\left(37^{\circ} \mathrm{C}\right)$, and 


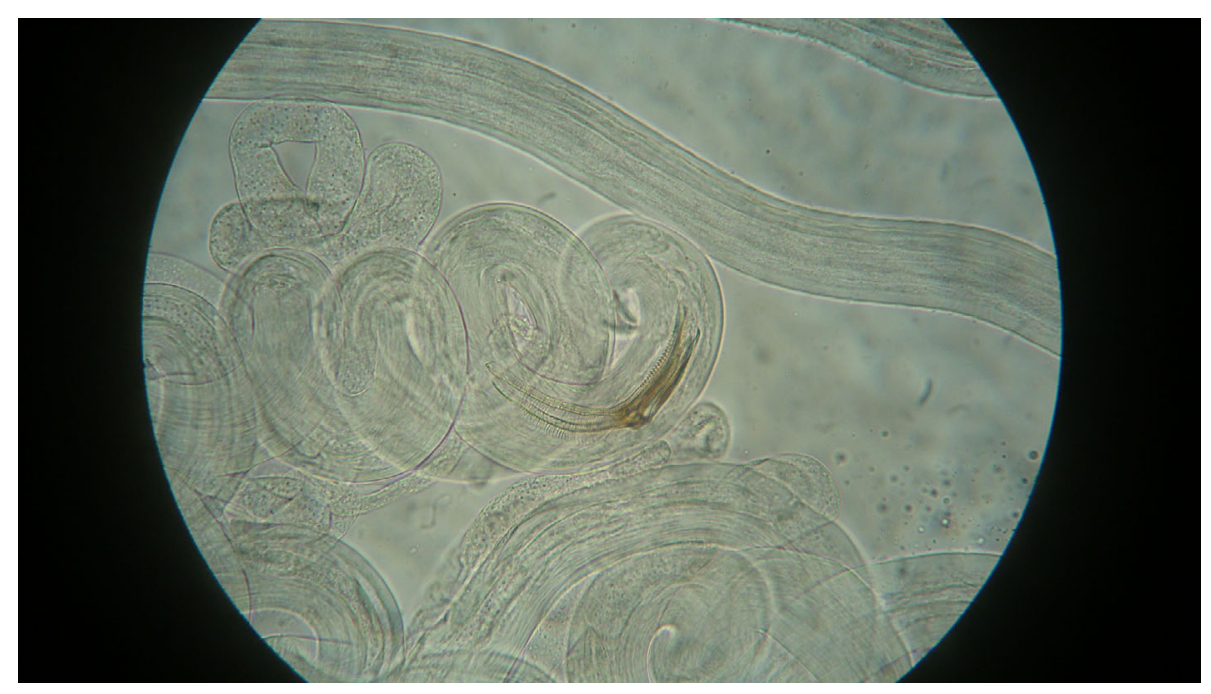

Fig. 1. Adult male of Muellerius capillaris

left overnight in funnels of plastic with a tube at the end. Finally, decanting worms at the bottom of the tube were recovered. Adults were identified following Boev (1975). Several portions of lung tissue were collected from the sites where macroscopic lesions were observed. They were processed using the classical histological techniques of paraffin embedding, and were then sectioned $(5 \mu \mathrm{m})$ and stained with hematoxilyn-eosin.

Data between goat and sheep faecal samples, at a level of significance of $5 \%$, were analysed by Chi-square test.

\section{Results}

The results of $\mathrm{L} 1$ recovery from fecal samples are shown in Table 1. Prevalence of L1-positive feces in flock B was higher (Chi $4.99 ; \mathrm{p}<0.03)$ in goats $(66.6 \%)$ than in sheep (40\%); by contrast, in flock $\mathrm{C}$, positive fecal pools were found only in sheep. Pooled samples collected from young goats of flocks D and F were negative. Adults ( 9 females and 2 males) and L1 of $M$. capillaris were recovered from lung nodules (Figs. 1 and 2).

In all cases of goat lungs, the observed macroscopic lesions included multiple subpleural $3-15 \mathrm{~mm}$ nodules, frequently coalescing. They were grayish-yellow and, in some cases, greenish. Sectioned nodules appeared solid and dry. All the lesions were mostly concentrated in the caudal lobules, mainly on the dorsal side. Histological analysis showed areas of bronchointerstitial pneumonia characterized by the presence of larval and adult stages of the intralesional parasite (Fig. 3). Adult stages were characterized by the presence of coelomic cavity and muscles, intestine, and in some cases, uterus full of eggs. An abundant mixed inflammatory infiltrate was observed in the alveolar septa surrounding these parasite accumulations, with a prevalence of lymphocytes, monocytes and occasionally some eosinophils. Giant cells were observed surrounding some larval stages, and a greater eosinophil concentration. Finally, hyperplasia of smooth muscle and an abundant mixed exudate were observed in some bronchioli.

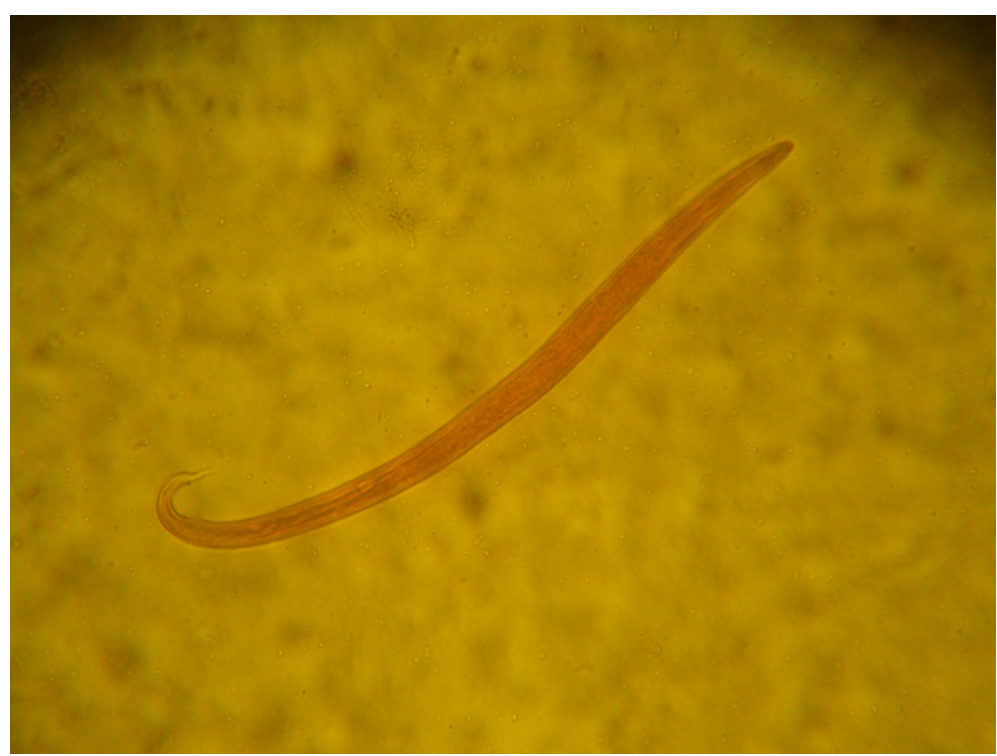




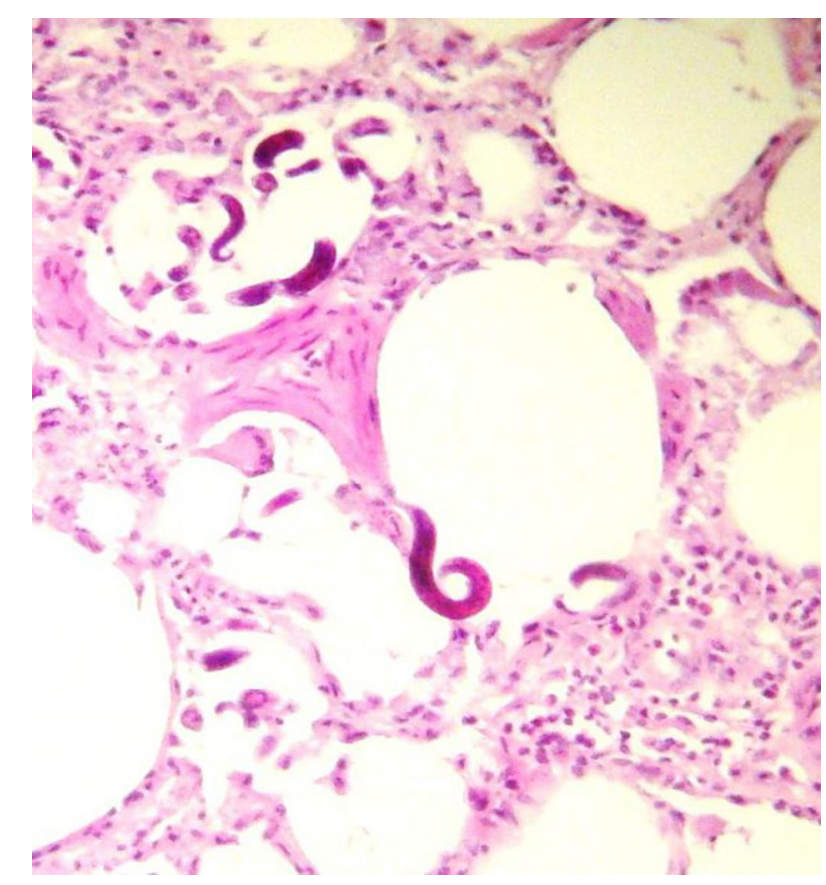

Fig. 3. Lung alveolar septa with first-stage larvae of Muellerius capillaris

\section{Discussion}

The recovery of L1 and adult forms of $M$. capillaris from samples collected from several flocks of goats and sheep in Salta and Jujuy, Argentina, on different dates and locations confirms for the first time the presence of this protostrongylid in the country. Previously, only Dictyocaulus filaria was recovered from small ruminant lungs (Suarez, 2007) and one report of an undescribed protostrongylid nematode from the pampas deer was cited (Carreno et al., 2012). Although it was possible to estimate the prevalence of animals infected with $M$. capillaris L1 only in two flocks (A and B, Table 1) where individual samples were analyzed, the results of the pooled samples suggest that the presence of $M$. capillaris was very variable among flocks and ecological zones. This variability was also observed in other regions, where prevalence ranged between $12 \%$ and 80 \% (Goncalves et al., 1980; Cabaret, 1986; Alemu et al., 2006; López et al., 2011).

The differences observed within the climatic environment of Lerma Valley (greater prevalence of $M$. capillaris in flocks A and B) might be due to the higher environmental humidity in the sites where these flocks are kept than in the location of flocks C, D and E. Higher humidity would provide a more favorable condition for the development of intermediate hosts. However, M. capillaris was also recovered from an arid environment, although with lower prevalence, such as flock F in Quebrada de Humahuaca. The more intensive exploitation regime of $\mathrm{F}$ might have provided higher chances of host infection. In Zaragoza, also an arid region, Uriarte et al. (1985) observed a greater prevalence of $M$. capillaris (55.2\%) in animals grazing on irrigated pastures than in animals present in non-irrigated pastures $(37.9 \%)$.
Regarding the difference in the presence of $M$. capillaris among host species, surprisingly the pools of feces from sheep were positive only in flock $\mathrm{C}$. These findings are not consistent with results reported in the literature, which indicate higher susceptibility of goats as a host of $M$. capillaris (Cabaret, 1984), but such difference is probably due to a small sample size taken only on two dates. By contrast, $M$. capillaris was not detected in the arid Puna of Jujuy, at (3500 $\mathrm{m}$ a.s.1.), an area subjected to an extensive sheep management.

Pool samples taken from young goats in D and F were negative, which is consistent with previous results reporting that $M$. capillaris is much more abundant in adult goats and sheep (Cabaret, 1984). Both macroscopic lesions and their histopathological description coincide with previous reports (Caswell \& Williams, 2007).

Although the present findings confirm the presence of $M$. capillaris in goat and mixed goat and sheep flocks in Lerma Valley (Salta) and Quebrada de Humahuaca (Jujuy), further research is necessary to elucidate which species of snails and slugs are associated with this nematode's life cycle, which factors favor its development, and how these and other management factors affect seasonal abundance and probable harmful effects of $M$. capillaris in the different regions of northwestern Argentina.

\section{References}

Alcaino, H., Gorman, T. (1999): Parásitos de los animales domésticos en Chile. Parasitol. Día, 23 (1 - 2): 33 41. DOI: 10.4067/S0716-07201999000100006

Alemu, S., Leykun, E. G., Ayelet, G., Zeleke, A. (2006): Study on small ruminant lungworms in northeastern Ethiopia. Vet. Parasitol., 142: 330 - 335. DOI 10.1016/j.vetpar.2006.07.008.

BERRAG, B., CABARET, J. (1996): Impaired pulmonary gas exchange in ewes naturally infected by small lungworms. Int. J. Parasitol., 26: 1397 - 1400. DOI: 10.1016/S00207519(96)00132-4

BoEv, S. N. (1975): Protostrongylidae (Leiper, 1926). In: Ryzhikov, M. M. (Ed) Editions de l'Academic des Sciences d' URSS. Volume XXV. Moscow, pp. 160 - 166 CABARET, J. (1981): Réceptivité des mollusques terrestres de la région de Rabat a l'infestation par les protostrongles dans les conditions expérimentales et naturelles. Thèse Université Pierre et Marie Curie et Muséum National d'Histoire Naturelle, Paris

CABARET, J. (1984): Sheep and goats. Epidemiology of protostrongylids lungworms infections. Int. Goat Sheep Res., 2 : $142-152$

CABARET, J. (1986): Repartition geographique des protostrongylides des ovins. Fréquence et importance de cette parasitose pulmonaire en Europe et en Afrique du Nord. Epidémiol. Santé Anim., 10: 61-72.

Carreno, R. A., Caporossi, D., Beade, M. S., Marull, C. A., Uhart, M. M., Markwardt, D. D., Nadler, S. A. (2012): Discovery of an undescribed protostrongylid nematode from the endangered pampas deer (Ozotoceros 
bezoarticus celer) in Argentina. J. Wildl. Dis., 48: 724 731. DOI: 10.7589/0090-3558-48.3.724

CASWEll, J. L., WiLliams, K. J. (2007): Respiratory system. In: GRANT MAXIE, M. (Ed) Jubb, Kennedy and Palmer's Pathology of Domestic Animals. Fifth Ed. Sounders, Elsevier, Vol. 2, C. 5, pp. $626-627$

Goncalves, P. C., Dos Santos, J. O. P., Ueno, H. (1980): Muellerius capillaris in sheep: occurrence and identification of adults. Pesq. Agropec. Bras., 15: $137-141$

López, C. M., Fernández, G., Viña, M., Cienfuegos, S., PAnAdero, R., VÁzQUez, L., Díaz, P., PATO, J., LAGO, N., DACAL, V., DíEZ-BAÑos, P., Morrondo, P. (2011): Protostrongylid infection in meat sheep from Northwestern Spain: Prevalence and risk factors. Vet. Parasitol., 178: 108 - 114. DOI: 10.1016/j.vetpar. 2010.12.038

MACHADO, T. M. M, LIMA, W. S. (1988): Muellerius capillaris (Mueller, 1889) em caprinos no Estado de Minas Gerais. Arq. Bras. Med. Vet. Zoot., 40: 69 - 70

NimMO, J. S. (1979): Six cases of verminous pneumonia (Muellerius sp.) in goats. Can. Vet. J., 20: $49-52$

PANDEY, V. S., CABARET, J., FiKRI A. (1984): The effect of strategic anthelmintic treatment on the breeding performance and survival of ewes naturally infected with gastrointestinal strongyles and protostrongylids. Ann. Rech. Vet., 15: $491-495$

Papadopoulos, E., Sotiraki, S., Himonas, C., FthenaKIS, G. C. (2004): Treatment of small lungworm infestation in sheep by using moxidectin. Vet. Parasitol., 121: $329-$ 336. DOI: 10.1016/ j.vetpar 2004.02.026
Pybus, M. J., Shave, H. (1984): Muellerius capillaris (Mueller, 1889) (Nematoda: Protostrongylidae): an unusual finding in Rocky Mountain bighorn sheep (Ovis canadensis canadensis shaw) in South Dakota. J. Wildl. Dis., 20: $284-288$

SuÁrez, V. H. (1997): Diagnóstico de las parasitosis internas de los rumiantes en la región de invernada. Técnicas e Interpretación. Bol. Divulgación Técnica (INTA-Anguil, Argentina), 56, $50 \mathrm{p}$.

SuÁrEZ, V. H. (2007): Epidemiología y control de los nematodes gastrointestinales en el oeste de la región pampeana. In: SuÁrez, V. H., OlaecheA, F. V., Rossanigo, C. E., ROMERo J. R. (Eds) Enfermedades parasitarias de los ovinos y otros rumiantes menores en el cono sur de América. Ediciones INTA, Arg., PT. 70, pp. $9-14$

Thomson, E. F., Gruner, L., BahHady, F., Orita, G., Termanini, A., Ferdawi, A. K., Hreitani, H. (2000): Effects of gastro-intestinal and lungworm nematode infections on ewe productivity in farm flocks under variable rainfall conditions in Syria. Livest. Prod. Sci., 63: 65 - 75. DOI 10.1016/S0301- 6226(99)00111-6

Uriarte, J., CABARET, J., TANCO, J. A. (1985): The distribution and abundance of parasitic infections in sheep grazing on irrigated or non-irrigated pastures in NorthEastern Spain. Ann. Rech. Vét., 16: 321 - 325

VAn WyK, J. A., Cabaret, J., Michael, L. M. (2004): Morphological identification of nematode larvae of small ruminants and cattle simplified. Vet. Parasitol., 119: 277 306. DOI 10.1016/j.vet.par.2003.11.012 